\title{
Relationship between Self-Concept and Commitment to Assignments Work Motivation of Citizens Learning in Shopy Course and Training Institutions Tanjung Balai City
}

\author{
Rusydi Ananda ${ }^{1}$, Shopiana ${ }^{2}$ \\ ${ }^{1}$ Lecturer in Faculty of Tarbiyah and Teacher Training, State Islamic University of North Sumatra UINSU, \\ Medan, Indonesia \\ ${ }^{2}$ Master Student in Faculty of Tarbiyah and Teacher Training, State Islamic University of North Sumatra \\ UINSU, Medan, Indonesia \\ rusdiananda.1972@gmail.com
}

\section{Abstract}

The purpose of this study was to find out: (1) a positive and significant relationship between self-concept and work motivation of the learning citizens, (2) a positive and significant relationship between commitment to the task and work motivation of the citizens, and (3) a positive and significant relationship between self-concept and commitment to the task together with the work motivation. The study population was all citizens learning 54 Tanjung Balai City Course and Training Institute, totaling 54 people. The entire population was sampled as a study. The research instrument used was a Likert scale questionnaire. Requirement test is performed to test the normality, linearity, and independence of the independent variables. Data analysis techniques used correlation and regression and simple correlation and regression and multiple correlations at the significance level $\alpha=0.05$. The research findings show: (1) there is a positive and significant relationship between self-concept and the work motivation of citizens learning. It means that the higher and more positive self-concept, the higher and more positive is work motivation by making an effective contribution of $13.82 \%$. (2) There is a positive and significant relationship between commitment to the task and work motivation of citizens learning. This means that the higher and more positive the commitment to the task, the higher and more positive is the work motivation of the citizens learning by making an effective contribution of $8.74 \%$, and (3) there is a positive and significant relationship together between self-concept and commitment to the task with the work motivation of citizens learning. This means that the higher and more positive the self-concept and commitment to the task, the higher and more positive is the work motivation of the citizens studying the Tanjung Balai Shopy Course and Training Institute by making an effective contribution of $22.60 \%$.
Keywords

self-concept; commitment to assignments, workmotivation

\section{Introduction}

One of the fundamental things that affects the improvement of the quality of human resources is work motivation, in this case work motivation in performing its tasks. In this case Anoraga and Suyati (1995: 85) factors that influence motivation are as follows: (1) 
personal needs, (2) the goals and perceptions of people or groups concerned, and (3) in what ways the needs and the goal is realized.

One indicator that can be used to measure organizational and individual achievement is performance through the influence of motivation. Motivation is a very important factor for the development of agencies, both now and in the future. Motivation is an impulse that is done so that a person can do a job or action in accordance with the desired to achieve the goals set (Ningsih, 2018).

Work motivation is the behavior exhibited by learning citizens in their willingness to do work that is relevant to their skills in their field of work. Work motivation needs to be evaluated for improvement, with the hope that performance will get better. Expectations of that performance will be achieved with an increase in self-concept and commitment to the task.

Various factors that influence the formation of maximum work motivation, in this case the researcher focuses on variables that affect work motivation are self-concept and commitment to the task. A strong self concept will give birth to a strong commitment to carry out the tasks carried out by a learning citizen which in turn can increase the motivation of a learning citizen to work. Increasing self-concept, the higher work motivation. Therefore, it can be suspected the influence of self-concept on work motivation of learning citizens.

Furthermore, related to the realization of good work motivation, it is inseparable from the effective commitment to the task on the individual. In this case commitment is the awareness to be actively involved in carrying out the task. Someone who has a sense of responsibility towards the task tends to have good work motivation. But, without this sense of responsibility and awareness, a person often ignores discipline in the task.

Commitment is a determination in a person to accept or reject one or more goals, and determine the actions or activities. Someone who has made a commitment to himself will be able to work hard and be responsible for their duties. Means, committed people allegedly tend to have awareness of their duties. Individuals who have a strong commitment will provide the best work performance for the country and the best service for the community, and of course performance in the office will also improve.

\section{Review of Literature}

Davies and Newstrom (2001: 101) define work motivation as a combination of psychology that is very complex in every person. Individuals are described through three elements, namely: (1) guidance and focus on behavior, in this case several positive factors include dependence, creativity, timeliness, while several factors of dysfunction include delays, attendance, and low performance; (2) the level of effort or work that is making a full commitment to get better results; and (3) determination of behavior, i.e. repetition in giving effort or work results that are too fast.

John and Goerge (2005: 175) mention work motivation is a psychological need in a person that determines the direction of one's behavior in the organization that causes movement, direction, effort, and persistence in facing obstacles to achieve a goal. Munandar (2006: 323) states that work motivation is a process in which needs encourage a person to carry out a series of activities that lead to the achievement of certain objectives. Goals that, if successfully achieved, will satisfy or meet those needs.

Robbins (1996: 200) provides a definition of work motivation as a form of willingness to spend a high level of effort for organizational goals, which is conditioned by the ability of 
the effort to meet some individual needs. While Wagner and Hollenbeck (2009: 81) states that someone who is motivated to work will continue to want to learn new things to improve his work performance.

McClelland as quoted by Mangkunegara (2000: 104) suggests several characteristics of people who have high achievement motivation, including: (1) having a high level of personal responsibility, (2) dare to take and carry risks, (3) have realistic goals, (4) having a comprehensive work plan and striving to realize the objectives, (5) utilizing real feedback on all activities carried out, and (6) looking for opportunities to realize the programmed plan.

Based on the theory described above, the researcher means that in the study what is meant by individual work motivation is the driving force that creates the excitement of one's work, with all the efforts to achieve satisfaction in order to achieve organizational goals and personal goals. Indicators of work motivation are: (1) salary received, (2) incentives, (3) selfesteem, (4) meeting spiritual needs, (5) meeting participation needs, (6) placement of individuals in appropriate places, (7) create a sense of security in the future, (8) pay attention to the workplace environment, (9) pay attention to opportunities to progress and (10) create healthy competition.

Pudjijogyanti (1991: 3) explains the concept of self encompasses the whole individual's view of his physical dimensions, personal characteristics, motivations, weaknesses, intelligence, failure and so on. Burns (1993: 40) explains self-concept is the relationship between attitudes and beliefs about ourselves. Furthermore, self-concept according to Pudjijogyanti (1991: 5) can be divided into three things: (1) self-concept that is realized, namely the individual's view of his abilities, status and role, (2) social me or me according to others, namely the individual's view of how other people view or value themselves, and (3) I am ideal, that is, the individual's expectations about him or what he will become. So I ideal is the aspiration of every individual.

Furthermore Brooks as quoted by Rachmat (2008: 56) defines the concept of self as "those physical, social, and psychological perceptions of ourselves that we have derived from experiences and our interactions with others". Djaali (2009: 76) explains the concept of self is a person's view of himself which involves what he knows and feels about his behavior, the contents of his thoughts and feelings, and how his behavior affects other people. Whereas Dharma (2003: 60) explains self-concept is a picture that a person has about himself, which is formed through experiences gained from interactions with his environment.

Cage and Berliner (1998: 78) suggest that self-concept is related to self-confidence and various feelings about self-respect. Therefore, in this context, if we feel better or vice versa, then our confidence and appreciation for ourselves will be better or vice versa. The concept of self is a mental structure, a totality of thoughts, feelings in dealing with oneself. Every individual tends to develop self-concept based on various characteristics they have. Selfconcept will limit how a person feels about himself, what he might be able to do in the future, and how he assesses his own appearance.

Based on the above explanation it can be interpreted that the concept of self is the views, beliefs and evaluations of individuals against all their own circumstances that include all individual views of their physical dimensions, personal characteristics, motivations, weaknesses, intelligence, failure and so on. Indicators used to measure self-concept variables are: learning motivation and achievement, relationships or relationships with teachers and friends, responses to learning successes and failures, trust in one's own abilities, views on the future, and responses to criticism and praise. 
Commitment is a decision of someone with himself, whether he will do or not do an activity. So someone who already has a commitment then they will not hesitate in determining the attitude and responsibility for the decision taken. Someone who has a high commitment to the task will be able to work hard. This is done not only to himself but also to others. Schatz and Schatz (1995: 67) state that commitment is the most basic thing for everyone in their work. Without a commitment, the tasks given to him are difficult to carry out properly. High commitment to the task can cause motivation to do something with full sincerity.

Commitment can be in the form of attitude (attitudinal commitment) and commitment in the form of behavior (behavior commitment) as stated by Allen and Meyer (1991: 8) states that it is very important to differentiate between attitude commitment and behavioral commitment, because this difference in understanding will bring consequences to the way the measurement. Attitude commitment is more focused on explaining the process by which people will join an organization, and thinking about their relationship with the organization. In many ways, people think about and consider the level of appropriateness of goals and individual values whether they are the same as the goals and values of the organization. Behavioral commitment, on the other hand, is related to the process by which individuals become determinants in an organization and how they deal with various organizational problems.

Imron (1995: 19) states the commitment to the task is one of the desired qualities of working individuals. Because people who have commitment will be willing to remain in the organization and are willing to work for the achievement of organizational goals. A similar opinion was also expressed by Nawawi et al (1993: 4-5) that an effective organization would only exist if the organization could not be effective without the support of individuals who had high loyalty, committed to carry out tasks, were willing to remain in like and suffering and believing how valuable an organization is.

Wahjusumidjo (1999: 76) explains the commitment to the task is as a promise, responsibility, and attachment to decisions taken based on the attitudes and agreements adopted at the time and tends to crystallize these attitudes. This implies that commitment to the task arises based on the individual's attitude towards something. Commitment to the task is also stable because these attitudes undergo a process of becoming permanent.

According Sahertian (1994: 121) commitment to the task is one form of work attitude. Attitude has an important role in every aspect of life in the organization, for example the teacher's attitude towards salary, superiors, work and coworkers. As a form of work attitude, commitment reflects a person's feelings, likes or dislikes the institution at work. So that attitudes like this will lead to concern, attention, and a sense of responsibility of the teacher towards the work and institutions of work.

Based on the description above it can be concluded that task commitment is a concern for the task shown by the teacher through active roles, a sense of responsibility, and loyalty to his work assignments. Commitment is something that shows the level of teacher attention in carrying out their duties and responsibilities in school. Indicators of commitment to school are: (a) care for the task, (b) willingness to try, (c) enthusiasm for developing abilities, and (d) loyalty. 


\section{Research Method}

The research method used is correlational quantitative research. The study population was all citizens learning 54 Tanjung Balai City Course and Training Institute, totaling 54 people. The entire population was sampled as a study. The research instrument used was a Likert scale questionnaire. Requirement test is performed to test the normality, linearity, and independence of the independent variables. Data analysis techniques used correlation and regression and simple correlation and regression and multiple correlations at the significance level $\alpha=0.05$

\section{Discussion}

The variable data of self-concept of learning citizens was $77.78 \%$ in the high category and $22.22 \%$ in the medium category. As for the poor and low categories there are none. Thus it can be concluded that the self-concept of learning citizens in this study tends to be high, as evidenced by $77.78 \%$ of respondents included in the high category.

Commitment variable data on the task of learning citizens in the high category was $77.78 \%$ and the moderate category was $22.22 \%$. As for the poor and low categories there are none. Thus it can be concluded that the commitment to the task in this study tended to be high which the residents learned with $77.78 \%$ of respondents included in the high category.

The variable of work motivation of learning citizens in the high category was $53.70 \%$ and the medium category was $46.30 \%$. As for the poor and low categories there are none. Thus it can be concluded that the work motivation of learning citizens in this study tends to be high as evidenced by $53.70 \%$ of respondents included in the high category.

The coefficient between the variables of self-concept and work motivation of learning citizens is 0.386 with a coefficient of determination (r2) of 0.148 . Through the t test that has been done it turns out obtained tcount $=3.015$ while the value of ttable $=1.674$. Price of tcount (3.015) > ttable (1.674), this shows that there is a positive and significant relationship between self-concept variables and work motivation of citizens to learn in the form of linear and predictive relationships through the regression line $\hat{Y}=72.38+0.35 \mathrm{X} 1$. Based on this analysis it can be concluded that self-concept has a significant and positive and significant predictive relationship with the work motivation of learning citizens.

The coefficient between the commitment variable on the task of learning citizens with work motivation of learning citizens is 0.340 ) with a coefficient of determination (R2) of 0.116 . Through the $t$ test that has been done it turns out obtained tcount $=2.607$ while the value of ttable $=1.674$. Therefore tcount $(2.607)>$ ttable $(1.674)$, this shows that there is a positive and significant relationship between the commitment variable on the task of learning citizens with work motivation of learning citizens with linear and predictive relationships through the regression line regresi $=69.48+0,37 \mathrm{X} 2$. Based on the above analysis it can be concluded that the commitment variable on the task of learning citizens has a significant and positive and significant predictive relationship with the work motivation variable of learning citizens.

The multiple correlation coefficient between the variables of self-concept and commitment to the task of learning citizens to the variable of work motivation of learning citizens is 0.476. After performing the F test it turns out that Fcount (11.3) > Ftable (3.178) at $\alpha=0.05$ thus the multiple correlation coefficient is significant and positive. The coefficient of determination shows the contribution of the self-concept variable and the commitment 
variable on the task of learning citizens to the work motivation variable of learning citizens at $22.60 \%$ and the remaining $77.40 \%$ is estimated to come from other variables not included in this study. Furthermore it can be stated that the double relationship of the independent variable to the dependent variable is in the form of a predictive relationship with the regression equation $\hat{Y}=35.07+0.34 \mathrm{X} 1+0.33 \mathrm{X} 2$.

The self-concept variable gave effective contribution to the work motivation variable of learning citizens by $13.82 \%$ and the commitment variable to the task of learning citizens made an effective contribution to the work motivation variable of learning citizens by $8.74 \%$.

The first finding is that the self-concept variable shows a positive and significant relationship with the variable of work motivation of learning citizens with a correlation magnitude of 0.386 with a predictive line $\hat{Y}=72.38+0.35 \mathrm{X} 1$. The effective contribution given by the self-concept variable to the work motivation variable of learning citizens was $13.82 \%$. This data makes an opportunity to improve the self-concept of learning citizens.

The findings of this study indicate that the self-concept variable shows a positive and significant relationship with the work motivation variable of learning citizens. This is in line with the explanation. Djaali (2009: 76) explains the concept of self is a person's view of himself which involves what he knows and feels about his behavior, the contents of his thoughts and feelings, and how his behavior affects other people. Whereas Dharma (2003: 60) explains self-concept is a picture that a person has about himself, which is formed through experiences gained from interactions with his environment. Furthermore, these findings confirm the findings of previous studies including: (1) Sari et al (2016) research, (2) Wulanta et al (2016) research (3) Qalsum et al (2015) research and (4) Rahmania, Suntoro, Kanda research (2014).

The self-concept owned by the people learning Shopy Tanjung Balai City Course and Training Institute is not brought from birth but is formed after birth through continuous interaction with the environment. The concept of self is not solely determined by factors of external experience, but also by internal experience, because humans are not passive individuals who can be determined just like that by the environment, but individuals who actively react to themselves and their environment.

The self-concept of learning citizens of the Tanjung Balai City Shopy Course and Training Institute is ideas, thoughts, beliefs and convictions that individuals know about themselves and influence individuals in their relationships with others. An important factor in self-concept is that self-concepts are learned through individual experiences and interactions with others. The self-concept of learning citizens of the Tanjung Balai City Shopy Course and Training Institute is a subjective image of self and a complex mix of unconscious and conscious feelings, attitudes and perceptions. The concept of self provides individuals with a frame of reference that influences self-management of situations and individual relationships with others. Mismatch between certain aspects of personality and self-concept can be a source of conflict.

The second finding shows the commitment to the task of learning citizens shows a positive and significant relationship with the variable of work motivation of learning citizens with a magnitude of correlation of 0.340 with a predictive line $\hat{Y}=69.48+0.37 X 2$. Effective contribution given commitment variable on the task of learning citizens towards work motivation variables of learning citizens.

Research findings that show a positive and significant relationship between the variable commitment to the task of learning citizens with the variable work motivation of learning citizens in line with the explanations put forward by Sah understanding (1994: 44) 
manifesting commitment to the task is a tendency in a person to feel actively involved with a full sense of responsibility. An active role with a full sense of responsibility that is owned by someone, it will encourage it to plunge directly into an activity, must be able to set decisions for himself and to be carried out should. Because commitment to the task is a decision or agreement of someone with himself to do or not do, stop or continue an activity, then personnel who already have one of several alternatives that are considered good, do not hesitate in taking a stand.

The sense of caring citizens learn about a task and the interests of the public or organization, not only because of personal interests, will affect the commitment. Sah understanding (1994: 101) explains the commitment to the task is broader than caring, because in the sense of commitment to the task includes the meaning of effort and encouragement as well as considerable time.

Commitment to the task is not just an engagement, but it shows someone's willingness to be actively involved in an activity with high responsibility. However, it can be understood that participation and care are also indicators of commitment inherent in self-learning citizens of the Tanjung Balai City Shopy Course and Training Institute. Commitment is a decision of someone with himself, whether he will do or not do an activity. So if the people learn Shopy Tanjung Balai City Course and Training Institute which already has a commitment, then they will not hesitate in determining their attitude and take responsibility for the decision taken.

The third finding is the self-concept variable and the commitment variable on the task of learning citizens together showing a positive and significant relationship to the variable of work motivation of learning citizens with a correlation magnitude of 0.476 and a determinant coefficient of 0.226 or $22.60 \%$ with a predictive line $\hat{\mathrm{Y}}=35.07+0,34 \mathrm{X} 1+0,33 \mathrm{X} 2$. Furthermore, if further examined the effective contribution of the two variables, namely the self-concept variable and the commitment variable to the task of learning citizens, the biggest effective contribution is given by the self-concept variable to the work motivation of learning citizens, which is $13.82 \%$.

Work motivation is the behavior exhibited by the residents of the Tanjung Balai City Shopy Course and Training Institute in their willingness to do work that is relevant to their skills in their field of work. Work motivation needs to be evaluated for improvement, with the hope that performance will get better. Expectations of that performance will be achieved with an increase in self-concept and commitment to the task.

Various factors that influence the formation of work motivation of learning citizens of the Tanjung Balai City Shopy Course and Training Institute are maximum, in this case the researcher focuses on the variables that influence work motivation are self-concept and commitment to the task.

The self-concept of learning citizens of the Tanjung Balai Kota Shopy Course and Training Institute will give birth to a strong commitment to carry out the tasks carried out by a learning citizen which in turn can increase the work motivation of a learning citizen. Increasing self-concept, the work motivation of citizens to learn Shopy Training Center and Training Institute in Tanjung Balai City is getting higher. Therefore, it can be suspected the influence of self-concept on work motivation of learning citizens.

On the other hand, commitment to the task of learning citizens of the Tanjung Balai City Shopy Course and Training Institute is closely related to the active role, sense of care and responsibility of a person towards the task. Residents learn Shopy City Course and Training Institute of Tanjung Balai City who have a concern for the task, so he tends to have compliance with the provisions of his duties. Or if someone who has a high sense of 
responsibility, then he tends to have high work motivation. Because with these responsibilities someone is very likely to have loyalty to their duties.

Commitment to the task is also a determination in the self-learning citizens of the Tanjung Balai City Shopy Course and Training Institute to accept or reject one or more of its objectives, and determine their actions or activities. Someone who has made a commitment to the task for himself will be able to work hard and be responsible for his duties. Means, individuals who are committed to the task allegedly tend to have an awareness of the task by carrying out tasks with a sense of responsibility so that the behavior of the tasks that become his responsibility ultimately leads to an increase in work motivation of the citizens studying the Tanjung Balai City Shopy Course and Training Institute.

\section{Conclusion}

The conclusions of the study are: (1) there is a positive and significant relationship between self-concept and work motivation of learning citizens by making an effective contribution of $13.82 \%$. This can be interpreted that variations that occur in self-concept variables of $\mathrm{r} 13.82 \%$ can be predicted in increasing work motivation of learning citizens, (2) there is a positive and significant relationship between commitment to the task of working motivation of learning citizens by making effective contributions of $8,74 \%$. This can be interpreted that the variation that occurs in the commitment to the task of $8.74 \%$ can be predicted in increasing the work motivation of learning citizens, and (3) there is a positive and significant relationship together between self-concept and commitment to the task with work motivation of citizens learning by making effective contributions of $22.60 \%$. This means that $22.60 \%$ of the variations that occur in the work motivation of learning citizens can be predicted by the self-concept variable and the commitment variable on the task.

Suggestions that can be delivered are: (1) the head of the work unit should be able to support the self-concept and commitment to the task by providing involving citizens to learn by giving citizens the opportunity to learn to develop their potential and last but not least is exercising normative rights that are learning residents are accepted according to the procedure, (2) to the relevant Ministries to improve the competence and professionalism of the learning citizens by providing training, and (3) to other researchers that this research needs to be followed up specifically with regard to the different variables that contribute on work motivation.

\section{References}

Ananda, Rusydi dan Fadhli, Muhammad. Statistik Pendidikan. Teori Dan Praktek Dalam Pendidikan. Medan; Widya Puspita, 2018.

Allen, N.J \& Meyer, P.J. Commitment in the Workplace; Theory, Research and Application. (London: Sage Publication, 1991.

Burns, R.B. Konsep Diri, Teori Pengukuran, Perkembangan dan Perilaku, Terj. Eddy, Jakarta: Arcan, 1993.

Cage, L.N. dan Berliner, David C. Educational Psychology, New York: Hougton Mifflin Company, 1998.

Davies, Keith dan Newstrom, John W. Organizational Behavior: Human Behavior at Work, New York: Mc. Graw-Hill Companies, Inc. 2001.

Dharma, Agus. Manajemen Prestasi Kerja, Jakarta: Rajawali Pers, 2003. 
Djaali. Psikologi Pendidikan. Jakarta: Rineka Cipta, 2009.

Imron, Ali. Pembinaan Guru di Indonesia. Malang: Pustaka Jaya, 1995.

John, Gareth R. dan George, Jennifer. M. Contempory Management. USA: McGraw-Hill International Edition, 2005.

Mangkunegara, A.A Anwar Prabu. Manajemen Sumber Daya Manusia Perusahaan, Bandung: Remaja Rosdakarya, 2000.

Munandar, Ashar Sunyoto. Psikologi Industri dan Organisasi. (Jakarta: Universitas Indonesia, 2006.

Nawawi, Hadari dan Martini, Hadari. Kepemimpinan Yang Efektif. Yogyakarta: Gadjah Mada University Press, 1993.

Ningsih, S. (2018). The Relationship between Motivation and Worker's Productivity in Civil Registration and Population Department, Asahan Regency, Indonesia. Budapest International Research and Critics Institute (BIRCI-Journal), 1(2): 148-160.

Pudjijogyanti, Clara Roro. Konsep Diri Dalam Pendidikan, Jakarta: Arcan, 1991.

Qalsum, Ummi., Nurhayati, dan Yani, Ahmad. Hubungan Antara Konsep Diri Dan Motivasi Berprestasi Dengan Hasil Belajar Fisika Peserta Didik SMA Di Kota Makassar. Jurnal Sains dan Pendidikan Fisika. Jilid 11, Nomor 2, Agustus 2015.

Rakhmat, Jalaluddin. Psikologi Komunikasi. Bandung: Rosda Karya, 2008.

Robbins, Stephen P. Essentials of Organizational Behavior. New Jersey; PrenticeHall International, Inc. 1996

Sahertian, Piet. A. Profil Pendidikan Profesional. Yogyakarta: Andi Offset, 1994.

Sari, Winda Permata., Taufik., dan Sukmawati, Indah. Hubungan Konsep Diri Akademik Dengan Motivasi Berprestasi. Jurnal: Educatio Jurnal Pendidikan Indonesia 36 Volume 2 Nomor 2, Oktober 2016.

Schatz, K. \& Schatz L. Managing by Influence. New Jersey: Prentice Hall Inc, 1995.

Wagner, John A. dan Hollenbeck, John R. Organizational Behavior; Securingcompetitivo Advantage. New York: Upper Saddle River, Prentice Hall, 2009.

Wahyusumidjo. Kepemimpinan Kepala Sekolah. Jakarta: Rajagrafindo Persada, 1999.

Wulanta, Yany Garry., Boham, Antonius., dan Rembang, Meiske. Konsep Diri Karyawan Dalam Berkomunikasi Pasca Diistirahatkan (Studi Pada Karyawan PT. Pasifik Sakti Bersama Bitung). Jurnal: Acta Diurna Volume V. No.2. Tahun 2016. 